\title{
Exogenous porcine somatotropin administered to neonatal pigs at high doses can alter lifetime fat but not lean tissue deposition
}

\author{
Frank. R. Dunshea ${ }^{1,2} *$, Danny Suster ${ }^{1}$, Douglas J. Kerton ${ }^{1}$ and Brian J. Leury ${ }^{2}$ \\ ${ }^{1}$ Victorian Institute of Animal Science, Werribee 3030, Australia \\ ${ }^{2}$ The University of Melbourne, Melbourne 3010, Australia
}

(Received 2 January 2002 - Revised 5 January 2003 - Accepted 17 January 2003)

\begin{abstract}
The growth rate of the young pig is generally much less than its potential and may be constrained by endocrine status as well as nutrient intake. The aim of the present study was to determine whether porcine (p) somatotropin (ST) treatment of the sucking pig could alter subsequent body composition. Twelve mixed-parity cross-bred sows with an average litter size of ten piglets were used to nurse pigs for the present study. On day 1 of lactation, the median two male pigs (by weight) from each litter were randomly allocated to one of two doses of pST ( 0 or $1 \mathrm{mg} / \mathrm{kg}$ per d) until weaning on day 21. Pigs were weaned and offered feed ad libitum until slaughter at $134 \mathrm{~d}$ of age. Body composition was measured using dualenergy X-ray absorptiometry (DXA) at 21, 49, 77, 105 and $133 \mathrm{~d}$ of age. There was no significant difference in growth rates between day 1 and 21 of lactation in pigs injected with either saline $(9 \mathrm{~g} / \mathrm{l} \mathrm{NaCl} / \mathrm{l})$ or $\mathrm{pST}(258$ v. $246 \mathrm{~g} / \mathrm{d}$ for control and pST-treated pigs respectively, $P=0.61)$, and as a consequence there was no significant difference in liveweight at weaning $(7.13$ v. $6.84 \mathrm{~kg}, P=0.59)$. However, fat mass at weaning tended to be decreased $(1.18 v$. $0.96 \mathrm{~kg}, P=0.064)$, while the $\%$ fat in the body at weaning was significantly $(16.7 \mathrm{v} .13 .9 \%$, $P=0.008)$ decreased by exogenous pST treatment. In the immediate post-weaning period there was a reduction in lean tissue deposition $(347 v .300 \mathrm{~g} / \mathrm{d}, P=0.021)$ but no effect on fat deposition ( $35 v .33 \mathrm{~g} / \mathrm{d}, P=0.72$ ). Over the entire weaning-to-slaughter period, pST treatment of neonatal pigs decreased the rate of fat deposition $(130 v .112 \mathrm{~g} / \mathrm{d}, P=0.033)$, but had no effect on lean tissue deposition $(550 v .538 \mathrm{~g} / \mathrm{d}, P=0.49)$. Therefore, treatment of nursing pigs with high doses of pST for a short period before weaning may provide a means of reducing the fat content of pork and pork products.
\end{abstract}

Lactation: Somatotropin: Growth: Body composition: Neonate: Pig

The growth rate of the young pig is generally less than half its potential (Boyd et al. 1995) and may be constrained by endocrine status as well as nutrient intake. Although porcine (p) somatotropin (ST) increases lean tissue growth and decreases fat growth in grower and finisher pigs, the response to $\mathrm{pST}$ is often much less in younger pigs (Campbell et al. 1991). For example, young weaned pigs (about $10.0 \mathrm{~kg}$, age not given) did not exhibit any growth response to pST until after at least $10 \mathrm{~d}$ of treatment and even then the response was inconsistent (Harrell et al. 1997). This was despite elevated plasma insulin-like growth factor (IGF)-I and insulin levels and reduced plasma urea as a result of only $5 \mathrm{~d}$ with pST treatment (Harrell et al. 1997). In addition, pST administration at the doses used in finisher pigs $(0.06 \mathrm{mg} / \mathrm{kg})$ failed to increase plasma IGF-I or growth in neonatal sucking pigs, although there was limited evidence of subsequent growth responses (Dunshea et al. 1999). In contrast, Wester et al. (1998) found that a relatively high dose of exogenous pST $(1 \mathrm{mg} / \mathrm{kg})$ increased plasma IGF-I and growth over the first $7 \mathrm{~d}$ of life in artificially reared pigs.

The ontogeny of somatotropin and its receptors in the neonate has been well studied in a variety of species, although results specific to the pig are relatively scarce. Plasma ST in the young pig is very high around parturition, declines rapidly over the first week after birth, then remains constant until the second week of life before gradually increasing again over the next 5 weeks and declining once again (Buonomo \& Klindt, 1993; Matteri \& Carroll, 1997). ST then gradually declines up to at least 30 weeks of age (Klindt \& Stone, 1984; Owens et al. 1991; Harrell et al. 1997). These patterns of plasma growth hormone

\footnotetext{
Abbreviations: DXA, dual-energy X-ray absorptiometry; IGF, insulin-like growth factor; p, porcine; ST, somatotropin.

* Corresponding author: Associate Professor Frank R. Dunshea, fax +61 39742 0400, email Frank.Dunshea@nre.vic.gov.au
} 
concentrations are essentially the same as in vitro basal and growth hormone releasing hormone-stimulated ST release from cultured pituitary cells (Matteri \& Carroll, 1997). $\mathrm{ST}$ receptor mRNA has been found in the liver of the fetal (Duchamp et al. 1996) and neonatal (Brameld et al. 1995) pig and it increases over at least the first $20 \mathrm{~d}$ of life (Owens et al. 1990). Therefore, it appears that the ST receptor gene is being transcribed, but it is not known whether there are any functional receptors being produced. Alternatively, there may be some functional receptors that are resistant to ST but that may respond to high doses of exogenous pST.

The carry-over effects of pST treatment of the neonatal animal on growth and body composition are unclear. Evidence exists from in vitro studies that pST may inhibit pre-adipocyte differentiation and proliferation (Ramsey et al. 1987; Gerfault et al. 1999). If this were the case in vivo, neonatal pST treatment may have subsequent effects on fat deposition that would have important practical implications. Therefore, the aim of the following study was to determine whether a high dose of exogenous pST administered to neonatal pigs would alter pre-weaning and subsequent growth and body composition.

\section{Materials and methods}

All procedures involving animals were approved by the Victorian Institute of Animal Science Animal Ethics Committee.

Twelve mixed parity cross-bred sows with an average litter size of ten piglets were used to nurse pigs for the present study. All sows and litters were housed in farrowing crates in an insulated building maintained at $18-22^{\circ} \mathrm{C}$. The creep area was maintained at a temperature of $30-32^{\circ} \mathrm{C}$ through use of infrared lamps. Sows were offered $2.0 \mathrm{~kg}$ lactation diet/d containing $14.3 \mathrm{MJ}$ digestible energy, $160 \mathrm{~g}$ crude protein $(\mathrm{N} \times 6.25)$ and $9.3 \mathrm{~g}$ available lysine $/ \mathrm{kg}$ prior to farrowing. After farrowing, feed allowance was increased by $0.5 \mathrm{~kg} / \mathrm{d}$ until reaching ad libitum feed intake, for the remainder of the lactation. Piglets were denied access to both creep feed and water throughout the nursing period.

On day 1 of lactation the litters were weighed and two male pigs from each litter were selected and randomly allocated to either daily saline $(9 \mathrm{~g} / \mathrm{l} \mathrm{NaCl} / \mathrm{l})$ or recombinant $\mathrm{pST}(1 \mathrm{mg} / \mathrm{kg}$ body weight; Alpharma Animal Health, Toorak, Australia) injection until weaning on day 21. Pigs were weighed and pST doses adjusted every $3 \mathrm{~d}$. After weaning at $21 \mathrm{~d}$ of age pigs were placed in individual pens in the weaner shed and fed ad libitum. At 4 weeks post-weaning the pigs were transferred into an experimental grower shed and kept in a pen with their male littermates. For the last 4 weeks of the finishing period pigs were kept in individual pens to determine feed intake and average daily gain. Conventional wheat-based weaner (15.0 MJ digestible energy, $200 \mathrm{~g}$ protein and $12.0 \mathrm{~g}$ available lysine $/ \mathrm{kg}$ ), grower (14.0 MJ digestible energy, $185 \mathrm{~g}$ protein and $9.5 \mathrm{~g}$ available lysine $/ \mathrm{kg}$ ) and finisher diets (13.7 MJ digestible energy, $167 \mathrm{~g}$ protein and $7.5 \mathrm{~g}$ available lysine $/ \mathrm{kg}$ ) diets were fed ad libitum from 21 to 49,49 to 105 and 105 to $133 \mathrm{~d}$ of age respectively.
Body composition of pigs was measured using dual energy X-ray absorptiometry (DXA) (Hologic QDR4500, Waltham, MA, USA). Good overviews of the DXA technology and its underlying principals can be found in Laskey \& Phil (1996) and Kelly et al. (1998) and DXA has previously been used to measure body composition in pigs (Mitchell et al. 1996, 1998; Lukaski et al. 1999). Animals were scanned using DXA at weaning ( $21 \mathrm{~d}$ old), at transfer into the grower shed $(49 \mathrm{~d}$ old $)$, midway through the grower phase $(77 \mathrm{~d}$ old), commencement of finisher phase (105 d old) and just before slaughter (133 d old). Feed was removed from pigs $16 \mathrm{~h}$ prior to scanning to reduce the influence of gastointestinal contents on DXA measurements. Animals were anaesthetised using an intramuscularly administered cocktail of xylazine and ketamine $(0.05$ and $0.10 \mathrm{ml} / \mathrm{kg}$ body weight respectively) followed by respiratory administration of isoflurane. The chemical composition of the animal as estimated from the output generated by the algorithms in the proprietary DXA software were corrected using regression equations developed in our laboratory (Suster et al. 2000). Calibration of DXA was performed on a weekly basis with a step phantom to ensure accurate soft tissue results, and on a daily basis with a spine phantom to minimise baseline drift. Initial body composition of the piglets was estimated from live weight and the proportions of lean $(812 \mathrm{~g} / \mathrm{kg})$, fat $(65 \mathrm{~g} / \mathrm{kg})$ and ash $(23 \mathrm{~g} / \mathrm{kg})$ found in similar pigs from our herd (Auldist et al. 1997).

Pig growth and body composition data was analysed by one-way ANOVA with the main effect being dose of pST with sow as the blocking factor. All analyses were performed using GENSTAT (Payne et al. 1993).

\section{Results}

Growth performances of the pigs are shown in Table 1. There was no significant difference in growth rate between day 1 and 21 of growth in pigs injected with either saline $(9 \mathrm{~g} / \mathrm{l} \mathrm{NaCl} / \mathrm{l})$ or pST $(258$ v. $246 \mathrm{~g} / \mathrm{d}$ for control and pSTtreated pigs respectively, $P=0.61$ ) and as a consequence there was no significant difference in live weight at weaning $(7.13$ v. $6.84 \mathrm{~kg}, P=0.59)$. However, pigs previously treated with pST tended to eat less $(547 v .469 \mathrm{~g} / \mathrm{d}$, $P=0.097)$ and grow more slowly $(426$ v. $373 \mathrm{~g} / \mathrm{d}$, $P=0.085)$ after weaning than their control counterparts and as a consequence tended to be lighter at the end of the weaner period $(19.1 v .17 .0 \mathrm{~kg}, P=0 \cdot 078)$. Despite this, there were no significant differences in growth performance or live weight over the rest of the study (Table 1).

There was no effect of $\mathrm{pST}$ on lean tissue deposition of sucking pigs until weaning at $21 \mathrm{~d}$ of age $(211 v .210 \mathrm{~g} / \mathrm{d}$, $P=0.97$; Table 2). However, lean tissue deposition over the weaner period between 21 and $49 \mathrm{~d}$ of age was decreased by almost $14 \%$ by previous exogenous pST treatment $(347$ v. $300 \mathrm{~g} / \mathrm{d}, P=0 \cdot 021)$. Consequently, the total lean tissue mass of pigs previously treated with $\mathrm{pST}$ tended to be less at $49 \mathrm{~d}$ of age $(15.5 v$. $13.9 \mathrm{~kg}$, $P=0 \cdot 054)$. Despite this, there was no significant effect of pST treatment on lean tissue deposition over any other period of growth. Over the entire birth-to-slaughter 
Table 1. Effect of daily porcine (p) somatotropin (ST) injection from day 1 until $21 \mathrm{~d}$ of age on growth performance* (Mean values for six pigs per treatment group)

\begin{tabular}{|c|c|c|c|c|}
\hline & Saline† & pST & SED & $\begin{array}{c}\text { Statistical significance } \\
\text { of effect: } P\end{array}$ \\
\hline \multicolumn{5}{|l|}{ Live weight (kg) } \\
\hline Day 1 & 1.97 & 1.92 & 0.099 & 0.64 \\
\hline Day 21 & $7 \cdot 13$ & $6 \cdot 84$ & 0.517 & 0.59 \\
\hline Day 49 & $19 \cdot 1$ & $17 \cdot 0$ & 1.05 & 0.078 \\
\hline Day 77 & 41.4 & $38 \cdot 2$ & $2 \cdot 15$ & 0.17 \\
\hline Day 105 & 69.9 & $67 \cdot 8$ & 3.03 & 0.49 \\
\hline Day 133 & $101 \cdot 6$ & 99.2 & 3.69 & 0.53 \\
\hline \multicolumn{5}{|c|}{ Weaner performance $(21-49 d)$} \\
\hline Daily gain $(\mathrm{g} / \mathrm{d})$ & 426 & 373 & $28 \cdot 7$ & 0.097 \\
\hline Feed intake $(\mathrm{g} / \mathrm{d})$ & 547 & 469 & $40 \cdot 7$ & 0.085 \\
\hline Feed conversion ratio & 1.29 & 1.26 & 0.063 & 0.70 \\
\hline \multicolumn{5}{|c|}{ Finisher performance (105-133d) } \\
\hline Daily gain $(g / d)$ & 1132 & 1123 & $31 \cdot 8$ & 0.79 \\
\hline Feed intake $(\mathrm{g} / \mathrm{d})$ & 3158 & 3045 & $125 \cdot 0$ & 0.39 \\
\hline Feed conversion ratio & 2.79 & 2.72 & 0.076 & 0.33 \\
\hline
\end{tabular}

* For details of diets and procedures, see p. 796.

† $\mathrm{g} / \mathrm{l} \mathrm{NaCl} / \mathrm{l}$.

period there was no effect of neonatal pST on lean tissue deposition $(550$ v. $538 \mathrm{~g} / \mathrm{d}, P=0.49)$ or final lean tissue mass $(74.2$ v. $72.5 \mathrm{~kg}, P=0.49)$. Fat mass at weaning tended to be decreased $(1.18 v .0 .96 \mathrm{~kg}, P=0.064)$, while the $\%$ fat in the body at weaning was significantly $(16.7$ v. $13.9 \%, P=0.008)$ decreased by exogenous pST treatment (Table 3 and Fig. 1). While fat deposition was numerically lower over every stage of post-weaning

Table 2. Effect of daily porcine (p) somatotropin (ST) injection from 1 until $21 \mathrm{~d}$ of age on subsequent rates of tissue deposition*

(Mean values for six pigs per treatment group)

\begin{tabular}{|c|c|c|c|c|}
\hline & Saline† & pST & SED & $\begin{array}{c}\text { Statistical significance } \\
\text { of effect: } P\end{array}$ \\
\hline \multicolumn{5}{|c|}{ Lean deposition ( $\mathrm{g} / \mathrm{d})$} \\
\hline $1-21 d$ & 211 & 210 & $17 \cdot 1$ & 0.97 \\
\hline $21-49 d$ & 347 & 300 & $17 \cdot 4$ & 0.021 \\
\hline $49-77 d$ & 538 & 660 & $102 \cdot 9$ & 0.27 \\
\hline $77-105 d$ & 831 & 742 & $117 \cdot 4$ & 0.47 \\
\hline $105-133 d$ & 723 & 683 & 35.6 & 0.29 \\
\hline $21-133 d$ & 611 & 598 & $17 \cdot 9$ & 0.48 \\
\hline $1-133 d$ & 550 & 538 & $17 \cdot 0$ & 0.49 \\
\hline \multicolumn{5}{|c|}{ Fat deposition $(\mathrm{g} / \mathrm{d})$} \\
\hline $1-21 d$ & $52 \cdot 7$ & 41.9 & $5 \cdot 11$ & 0.059 \\
\hline $21-49 d$ & 34.9 & 33.4 & 4.09 & 0.72 \\
\hline $49-77 d$ & 98.8 & $89 \cdot 4$ & 9.51 & 0.36 \\
\hline $77-105 d$ & 167 & 146 & 14.1 & 0.20 \\
\hline $105-133 d$ & 273 & 232 & $16 \cdot 9$ & 0.039 \\
\hline $21-133 d$ & 144 & 125 & $7 \cdot 8$ & 0.045 \\
\hline $1-133 d$ & 130 & 112 & 6.9 & 0.033 \\
\hline \multicolumn{5}{|c|}{ Ash deposition ( $\mathrm{g} / \mathrm{d}$ ) } \\
\hline $1-21 d$ & $2 \cdot 31$ & $2 \cdot 10$ & 0.320 & 0.51 \\
\hline $21-49 d$ & 7.43 & 6.80 & 0.549 & 0.28 \\
\hline $49-77 d$ & $17 \cdot 6$ & $18 \cdot 2$ & 1.47 & 0.69 \\
\hline $77-105 d$ & $20 \cdot 2$ & 20.5 & 0.96 & 0.77 \\
\hline $105-133 d$ & $19 \cdot \overline{6}$ & $19 \cdot 2$ & 1.98 & 0.87 \\
\hline $21-133 d$ & $16 \cdot 3$ & $16 \cdot 2$ & 0.91 & 0.94 \\
\hline $1-133 d$ & 14.2 & 14.0 & 0.78 & 0.87 \\
\hline
\end{tabular}

${ }^{\star}$ For details of diets and procedures, see p. 796.

$\dagger 9 \mathrm{~g} / \mathrm{l} \mathrm{NaCl/l.}$ growth in pigs treated with pST as neonates, it did not reach significance until during the finisher phase when fat deposition was decreased by $15 \%(273$ v. $232 \mathrm{~g} / \mathrm{d}$, $P=0.039$ ). Over the entire weaning-to-slaughter period, neonatal pST treatment decreased the rate of fat deposition $(130 v .112 \mathrm{~g} / \mathrm{d}, P=0.033)$, final fat mass $(17.3 v .14 .9 \mathrm{~kg}$, $P=0.033)$ and the \% fat in the body $(18.5 \mathrm{v} .16 .6 \%$, $P=0.008$ ). However, there was no significant effect of neonatal pST treatment on $\mathrm{P} 2$ backfat at slaughter $(20 \cdot 2 \mathrm{v}$. $18.5 \mathrm{~mm}, P=0.22$; Fig. 1). There was no effect of neonatal pST treatment on ash deposition or whole-body ash content at any stage of growth.

Table 3. Effect of daily porcine (p) somatotropin (ST) injection from 1 until $21 \mathrm{~d}$ of age on subsequent body composition* (Mean values for six pigs per treatment group)

\begin{tabular}{rccll}
\hline & Saline† & pST & SED & $\begin{array}{c}\text { Statistical significance } \\
\text { of effect: } P\end{array}$ \\
\hline Lean content $(\mathrm{kg})$ & & & \\
21 d & 5.82 & 5.77 & 0.388 & 0.90 \\
$49 \mathrm{~d}$ & 15.5 & 13.9 & 0.74 & 0.054 \\
$77 \mathrm{~d}$ & 30.7 & 32.6 & 3.15 & 0.56 \\
$105 \mathrm{~d}$ & 53.9 & 53.4 & 2.09 & 0.80 \\
$133 \mathrm{~d}$ & 74.2 & 72.5 & 2.29 & 0.49 \\
Fat content $(\mathrm{kg})$ & & & \\
$21 \mathrm{~d}$ & 1.18 & 0.963 & 0.1062 & 0.064 \\
$49 \mathrm{~d}$ & 2.16 & 1.83 & 0.126 & 0.028 \\
$77 \mathrm{~d}$ & 4.96 & 4.36 & 0.320 & 0.098 \\
$105 \mathrm{~d}$ & 9.64 & 8.44 & 0.719 & 0.13 \\
$133 \mathrm{~d}$ & 17.3 & 14.9 & 0.92 & 0.033 \\
Ash content (g) & & & \\
$21 \mathrm{~d}$ & 0.092 & 0.086 & 0.0081 & 0.52 \\
$49 \mathrm{~d}$ & 0.300 & 0.271 & 0.0187 & 0.16 \\
$77 \mathrm{~d}$ & 0.801 & 0.783 & 0.0525 & 0.75 \\
$105 \mathrm{~d}$ & 1.37 & 1.36 & 0.074 & 0.90 \\
$133 \mathrm{~d}$ & 1.91 & 1.90 & 0.104 & 0.86 \\
\hline
\end{tabular}

${ }^{*}$ For details of diets and procedures, see p. 796. $\dagger 9 \mathrm{~g} / \mathrm{l} \mathrm{NaCl} / \mathrm{l}$. 


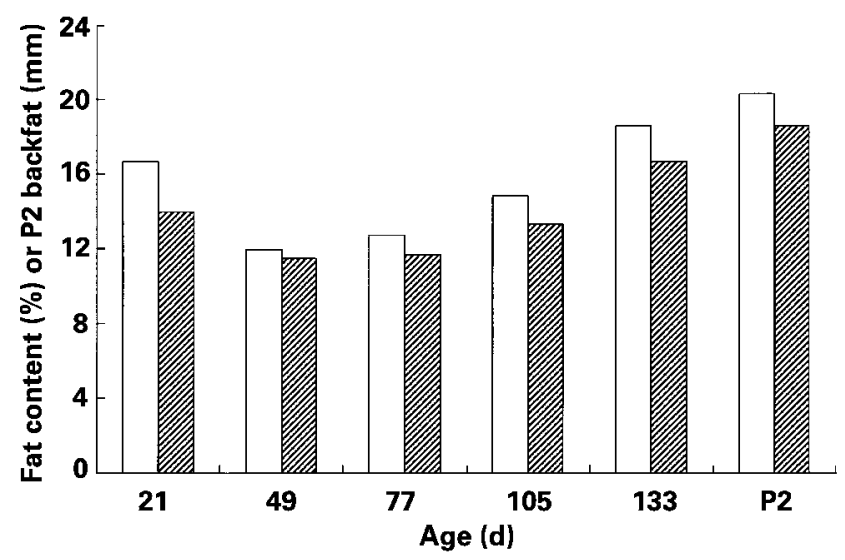

Fig. 1. Effect of neonatal porcine (p) somatotropin (ST) treatment on body fat content (\%) at various ages and on P2 backfat $(\mathrm{mm})$ at slaughter. $\square$, Control; $\mathbb{Z}$, pST. For details of procedures, see p. 796. Values are means for six pigs. Mean values were significantly different from those of the control group at $21 \mathrm{~d}(P=0.001)$, $49 \mathrm{~d}(P=0.14), 77 \mathrm{~d}(P=0.039), 105 \mathrm{~d}(P=0.055), 133 \mathrm{~d}(P=0.008)$, but not in P2 $(P=0.22)$.

\section{Discussion}

Treatment of neonatal pigs with pST caused a $20 \%$ decrease in the rate of fat deposition, despite there being no significant effect on the rates of lean tissue, ash and whole-body accretion up to weaning. Previously, we found that a much lower dose of pST $(0.06 v .1 .0 \mathrm{mg} / \mathrm{kg})$ had little effect on growth of sucking piglets (Dunshea et al. 1999). On the other hand, Wester et al. (1998) administered the same dose of pST as used in the present study $(1 \mathrm{mg} / \mathrm{kg})$ to neonatal pigs that were artificially reared (from $1 \mathrm{~d}$ of age) and found increases in growth rate and plasma IGF-I and IGF-binding protein-3. This indicates that the somatotrophic axis was functional in the neonatal pig, but sensitivity of expressed ST receptors was specifically reduced in the neonate as compared with an older pig. Wang et al. (1999) obtained adipose tissue from nursing neonatal pigs $(7 \mathrm{~d}$ old) and found that although basal and insulin-stimulated lipogenesis rates were low when compared with those observed in adipose tissue obtained from growing pigs, these rates could be further inhibited (about -78 and $-43 \%$ under basal and insulin-stimulated conditions respectively) by including pST in the medium. In another study involving pigs that were artificially reared, the antilipogenic responses to pST were evident at $25 \mathrm{~d}$ of age, although the response was markedly less than that normally observed in older pigs (Harrell et al. 1996). Similarly, nursing pigs treated with $0.3 \mathrm{mg} \mathrm{pST} / \mathrm{kg}$ per d from 1 day of age had $12 \%$ less backfat at the cessation of treatment at $25 \mathrm{~d}$ of age (Morel et al. 1999).

In the immediate post-weaning period there was no effect of previous pST treatment on fat deposition. However, as the animals grew older there appeared to be a progressive reduction in the rate of fat deposition, as indicated by the declining $P$ value with advancing age. Over the finishing phase, the rate of fat deposition was $15 \%$ lower in pigs previously treated with pST as neonates. It is possible that neonatal treatment of pigs with pST may decrease proliferation and/or differentiation of preadipocytes, thereby resulting in a reduction in total fat cells in the body. For example, Ramsay et al. (1987) found that the addition of pST to pre-adipocytes cultured in serum from decapitated fetuses (to remove pituitary hormones) resulted in an $80 \%$ reduction in complete differentiation. Likewise, Gerfault et al. (1999) found that pST inhibited both differentiation and proliferation of porcine pre-adipocytes obtained from neonatal pigs. If pST treatment of neonatal pigs also results in a decrease in porcine pre-adipocyte proliferation and differentiation in vivo then there would be fewer fat cells that would fill sooner. This in turn could result in the reduction in fat deposition becoming most pronounced during the finisher phase.

An alternative explanation may be that the reduced feed intake observed in the immediate post-weaning and possibly the grower (although not measured) periods in the present study may have contributed to an inhibition of pre-adipocyte differentiation and proliferation and subsequent reduced fat deposition in the finisher period. It is not anticipated that there was any effect of pST on feed intake during the sucking period, since milk intake was likely to be already limiting growth (Boyd et al. 1995; Dunshea et al. 2002). In addition, there was no effect of pST on growth rate, which in turn is closely related to milk intake in the nursing pig (King et al. 1989). However, there were clearly differences in the partitioning of nutrients in the sucking pig such that less energy was available for adipose tissue development and growth. Others have attempted to manipulate subsequent growth of pigs by manipulation of nutrient intake during the neonatal period. For instance, the classical studies of McMeekan $(1940 a, b, c)$ suggested that the level of feed intake up to 16 weeks of age could influence subsequent growth and carcass composition. Thus, McMeekan (1940c) found pigs that were restricted in feed intake and were then fed ad libitum had fatter carcasses at slaughter at $90 \mathrm{~kg}$ than pigs that were fed ad libitum throughout. However, more targeted restrictions in energy and/or feed intake in younger pigs, such as those used in the present study, suggest that the predominant effect is to reduce body fat with more subtle effects on lean tissue content (for review, see Young \& Sharma, 1973). For example, Martin et al. (1974) fed early weaned (3d of age) pigs on milk replacers that were either adequate in both energy and protein or deficient in either energy or protein until 4 weeks of age, after which they were fed standard diets ad libitum until slaughter at 23 weeks of age. Pigs fed the low-energy diet were lighter $(8.8 v .5 .5 \mathrm{~kg})$ at 4 weeks of age than the control pigs, with this effect still evident at 23 weeks of age $(87.7 v .73 .6 \mathrm{~kg})$. There was little effect of neonatal nutrition on a representative muscle weight (Semitendinosis), whereas the representative fat depot (perirenal fat) was $46 \%$ lighter in pigs fed the low-energy diet. Therefore, it is possible that the effects of neonatal pST treatment on lifetime fat deposition may be mediated indirectly through reduced feed intake during the immediate post-weaning or grower periods. Regardless of the mechanism, the practical implication is that neonatal and/or perinatal manipulation of fat metabolism can have subsequent effects on fat deposition. 
It is possible that a paired-feeding regimen during the post-weaning period could have been employed to determine whether effects of pST on subsequent growth and carcass composition were direct effects or the result of decreased feed intake. In this context, Neilsen (1964) found that effects of feed restriction from weaning at 3 weeks of age until $20 \mathrm{~kg}$ were most pronounced in pigs that were kept on a low plane of nutrition until slaughter at $90 \mathrm{~kg}$ than when fed ad libitum. However, it was felt that since the rate of fat deposition and voluntary feed intake are so closely linked, a restricted feeding regimen may have masked any effects of neonatal pST treatment on subsequent lean and fat deposition. For example, the reduced fat deposition that occurs in finisher pigs treated with pST is due to the induction of insulin resistance and resultant reduction in feed intake (Dunshea et al. $1992 a, b, c)$. From a practical point of view it is also unlikely that restricted feeding would be used to exploit neonatal pST treatment under commercial conditions.

Other workers have administered ST to pig and other species during the early period of growth and observed decreased backfat depths, although these effects have generally been transitory and not maintained until market weight. For example, Morel et al. (1999) treated neonatal pigs with $0.3 \mathrm{mg} \mathrm{pST} / \mathrm{kg}$ per $\mathrm{d}$ from 1 to $24 \mathrm{~d}$ of age and found differences in backfat depth at the cessation of treatment at 25 but not at $70 \mathrm{~d}$ of age or slaughter at $95 \mathrm{~kg}$. Similarly, McCutcheon et al. (1994) injected lambs with up to $0.3 \mathrm{mg}$ bovine ST/kg per $\mathrm{d}$ from birth until 11 weeks of age and observed a reduction in backfat at 8 but not 13 months of age. The responses may have been more sustained in the present study because a higher dose of pST was used at a critical stage in development, which in turn could have a more profound effect upon pre-adipocyte proliferation and differentiation. While treatment of neonatal rats with bovine ST for $21 \mathrm{~d}$ had no effect on body fat at 21 or $60 \mathrm{~d}$ of age, there was a decrease in body fat at $120 \mathrm{~d}$ of age (Kadim et al. 1996). As with the present study, there was little effect of neonatal ST treatment on lean tissue mass at any age.

There was a reduction in feed intake, lean tissue deposition and growth rate during the immediate postweaning period in the pigs that had been previously treated with pST as neonates. Very little work has been done on the effects of withdrawal of pST on subsequent growth performance of pigs, particularly in pigs so young. In one study, we found that there was very little effect of previous treatment $\mathrm{pST}$ of nursing pigs on growth performance in the immediate post-weaning period (Dunshea et al. 1999). On the other hand, Campbell et al. (1989b) reported that pigs treated with pST between 30 and $60 \mathrm{~kg}$ live weight had greater rates of lean and ash deposition, but unchanged fat deposition, over the growth phase between 60 and $90 \mathrm{~kg}$ live weight. More typically, a reduction in growth performance, often to levels below that of controls, is observed when pST treatment ceases (Bryan et al. 1990; Smith \& Kasson, 1990; Weeden et al. 1993). For example, Weeden et al. (1993) found that while daily gain was increased $(+11 \%)$ by pST treatment of finisher gilts, growth rate during the $35 \mathrm{~d}$ withdrawal period was dramatically decreased $(-51 \%)$. Similarly,
Sandles \& Peel (1987) treated identical calves with bovine ST $(0.6 \mathrm{mg}$ pituitary bovine ST/kg per d) from 3.5 months old for 21 weeks and found that although there was a significant increase in live weight at the end of the treatment period, this difference had disappeared 5 weeks later. Brumby (1959) also found that the improvements in live weight of calves treated with pituitary bovine ST were lost 5 weeks after cessation of treatment. Previous pST treatment of finisher pigs causes a large (about $50 \%$ ) reduction in the amount of pST contained in the pituitary (Campbell et al. 1989a). Therefore, it may be possible that pST treatment of neonatal pigs decreases pituitary pST production and/or delays the development of somatotrophic activity in the pituitary. A decrease in endogenous pST production in the immediate post-weaning period may be the cause of the reduced lean tissue deposition in weaner pigs previously treated with $\mathrm{pST}$.

Porcine somatotropin failed to stimulate lean tissue deposition in the sucking pig, most likely because sow's milk has a protein and lysine content much lower than the protein and lysine requirements of the young pig (Williams, 1976; Auldist et al. 1997; Dunshea et al. 2000). For example, the lysine content of sows' milk is about $0.7 \mathrm{~g} / \mathrm{MJ}$ gross energy, whereas the requirement of the neonatal pig is about $0.95 \mathrm{~g} / \mathrm{MJ}$ gross energy (Auldist et al. 1997). Therefore, lysine intake from sows' milk normally limits lean tissue growth of pigs. It is well established that at low levels of dietary lysine there is very little effect of pST on lean tissue deposition in grower (Campbell et al. 1990; Caperna et al. 1990; Krick et al. 1993) and finisher pigs (Campbell et al. 1991; King et al. 2000). Therefore, dietary lysine may have limited the lean tissue response to $\mathrm{pST}$ in the sucking pigs in both the present study and that of Dunshea et al. (1999), whereas the neonatal pigs used in the study of Wester et al. (1998) received a milk replacer containing adequate levels of lysine.

\section{Conclusions}

Treatment of neonatal pigs with very high doses of pST can decrease fat deposition during the neonatal period. More importantly, pST treatment of neonatal pigs can also decrease subsequent fat deposition, particularly over the finishing period. Therefore, treatment of nursing pigs with pST for a short period before weaning may provide a means of reducing the fat content of pork and pork products.

\section{Acknowledgement}

The authors are appreciative of the provision of Reporcin by Alpharma Animal Health.

\section{References}

Auldist DE, Stevenson FL, Kerr MG, Eason P \& King RH (1997) Lysine requirements of pigs from 2 to $7 \mathrm{~kg}$ liveweight. Animal Science 65, 501-507. 
Boyd DR, Kensinger RS, Harrell RJ \& Bauman DE (1995) Nutrient uptake and endocrine regulation of milk synthesis in mammary tissue of lactating sows. Journal of Animal Science 73, Suppl. 2, 36-56.

Brameld JM, Weller PA, Pell JM, Buttery PJ \& Gilmour RS (1995) Hormonal control of insulin-like growth factor-1 and growth hormone receptor mRNA expression by porcine hepatocytes in culture. Journal of Endocrinology 146, 239-245.

Brumby PJ (1959) The influence of growth hormone on growth in young cattle. New Zealand Journal of Agricultural Research 2 , $683-689$.

Bryan KA, Clark AM \& Hagen DR (1990) Effect of treatment with and subsequent withdrawal of exogenous porcine somatotropin on growth and reproductive characteristics of gilts. Journal of Animal Science 68, 2357-2361.

Buonomo FC \& Klindt J (1993) Ontogeny of growth hormone $(\mathrm{GH})$, insulin-like growth factors (IGF-I and IGF-II) and IGF binding protein-2 (IGFBP-2) in genetically lean and obese swine. Domestic Animal Endocrinology 10, 257-265.

Campbell RG, Johnson RJ, King RH, Taverner MR \& Meisinger DJ (1990) Interaction of dietary protein content and exogenous porcine growth hormone administration on protein and lipid accretion rates in growing pigs. Journal of Animal Science 68, 3217-3225.

Campbell RG, Johnson RJ, Taverner MR \& King RH (1991) Interrelationships between exogenous porcine somatotropin (pST) administration and dietary protein and energy intake on protein deposition capacity and energy metabolism of pigs. Journal of Animal Science 69, 1522-1531.

Campbell RG, Steele NC, Caperna TJ, McMurtry JP, Solomon MB \& Mitchell AD (1989a) Interrelationships between sex and exogenous growth hormone administration on performance, body composition and protein and fat accretion of growing pigs. Journal of Animal Science 67, 177-186.

Campbell RG, Steele NC, Caperna TJ, McMurtry JP, Solomon MB \& Mitchell AD (1989b) Effects of exogenous porcine growth hormone administration between 30 and 60 kilograms on the subsequent and overall performance of pigs grown to 90 kilograms. Journal of Animal Science 67, $1265-1271$

Caperna TJ, Steele NC, Komarek DR, McMurtry JP, Rosebrough RW, Solomon MB \& Mitchell AD (1990) Influence of dietary protein and recombinant porcine somatotropin administration in young pigs: Growth, body composition and hormone status. Journal of Animal Science 68, 4243-4252.

Duchamp C, Butron KA, Herpin P \& Dauncey MJ (1996) Perinatal ontogeny of porcine growth hormone receptor gene expression is modulated by thyroid status. European Journal of Endocrinology 134, 524-531.

Dunshea FR, Bauman DE, Boyd RD \& Bell AW (1992a) Temporal response of blood glucose and plasma metabolite and hormone concentrations during somatotropin treatment of growing pigs. Journal of Animal Science 70, 123-131.

Dunshea FR, Chung CS, Owens PC, Ballard FJ \& Walton PE (2002) Insulin-like growth factor-I and analogues can increase growth in artificially-reared neonatal pigs. British Journal of Nutrition 87, 587-593.

Dunshea FR, Harris DM, Bauman DE, Boyd RD \& Bell AW (1992b) Effect of somatotropin on non-esterified fatty acid and glycerol metabolism in growing pigs. Journal of Animal Science 70, 132-140.

Dunshea FR, Harris DM, Bauman DE, Boyd RD \& Bell AW (1992c) Effect of porcine somatotropin on in vivo glucose kinetics and lipogenesis in the growing pig. Journal of Animal Science 70, 141-151.

Dunshea FR, Kerton DK, Cranwell PD, Campbell RG, Mullan BP, King RH \& Pluske JR (2000) Dietary lysine requirements of heavy and light pigs weaned at 14 days of age. Australian Journal of Agricultural Research 51, 531-539.

Dunshea FR, King RH, Owens PC \& Walton PE (1999) Moderate doses of porcine somatotropin do not increase plasma insulin-like growth factor-I or insulin-like growthfactor binding protein-3. Domestic Animal Endocrinology 16, $149-157$.

Gerfault V, Louveau I \& Mourot J (1999) The effect of GH and IGF-I on preadipocytes from Large White and Meishan pigs in primary culture. General Comparative Endocrinology 114, 396-404.

Harrell DA, Matitashvili E \& Bauman DE (1996) Effects of exogenous porcine somatotropin on adipose tissue metabolism in young growing pigs. Journal of Animal Science 74, Suppl. 1, 143.

Harrell RJ, Thomas MJ, Boyd RD, Czerwinski SM, Steele NC \& Bauman DE (1997) Effect of porcine somatotropin administration in young pigs during the growth phase from 10 to 25 kilograms. Journal of Animal Science $\mathbf{7 5}$, $3152-3160$.

Kadim IT, McCutcheon SN, Purchas RW \& Wickham GA (1996) Manipulation of adult body composition by treatment of the neonatal rat with growth hormone and prolactin. Growth Regulation 6, 201-205.

Kelly TL, Berger N \& Richardson TL (1998) DXA body composition: theory and practice. Applied Radiation Isotopes 49, 511-513.

King RH, Campbell RG, Smits RJ, Morley WC, Ronnfeldt K, Butler K \& Dunshea FR (2000) Interrelationships between dietary lysine, sex, and porcine somatotropin administration on growth performance and protein deposition in pigs between 80 and $120 \mathrm{~kg}$ live weight. Journal of Animal Science 78, 2639-2651.

King RH, Toner MS \& Dove H (1989) Effect of porcine somatotropin administration before weaning on growth performance in pigs. In Manipulating Pig Production II, pp. 98 [JL Barnett and DP Hennessy, editors]. Werribee, Victoria: Australasian Pig Science Association.

Klindt J \& Stone RT (1984) Porcine growth hormone and prolactin: concentrations in the fetus and secretory patterns in the growing pig. Growth 48, 1-5.

Krick BJ, Boyd RD, Roneker KR, Beermann DH, Bauman DE, Ross DA \& Meisinger DJ (1993) Porcine somatropin affects the dietary lysine requirement and net lysine utilization for growing pigs. Journal of Nutrition 123, 1913-1922.

Laskey M \& Phil D (1996) Dual-energy X-ray absorptiometry and body composition. Nutrition 12, 45-51.

Lukaski HC, Marchello MJ, Hall CB, Schafer DM \& Siders WA (1999) Soft tissue composition of pigs measured with dual X-ray absorptiometry: comparison with chemical analysis and effects of carcass thickness. Nutrition 15, 697-703.

McCutcheon SN, Kadim IT, Wickham GA \& Purchas RW (1994) A prolonged change in body composition induced by endocrine manipulation of the neonate. Proceedings of the New Zealand of Animal Production 54, 51-54.

McMeekan CP (1940a) Growth and development in the pig with special reference to carcass quality characters. I. Age changes in growth and development. Journal of Agricultural Science 30, 276-343.

McMeekan CP (1940b) Growth and development in the pig with special reference to carcass quality characters. II. The influence of plane of nutrition on growth and development. Journal of Agricultural Science 30, 387-436.

McMeekan CP (1940c) Growth and development in the pig with special reference to carcass quality characters. III. Effect of plane of nutrition on the form and composition of the bacon pig. Journal of Agricultural Science 30, 511-568. 
Martin RJ, Ezekwe M, Herbein JH, Sherritt GW, Gobble JL \& Ziegler JH (1974) Effects of neonatal nutrtional experiences on growth and development of the pig. Journal of Animal Science 39, 521-526.

Matteri R \& Carroll JA (1997) Somatotroph function in the neonatal pig. Domestic Animal Endocrinology 4, 241-249.

Mitchell AD, Conway JM \& Potts WJE (1996) Body composition analysis of pigs by dual-energy X-ray absorptiometry. Journal of Animal Science 74, 2663-2671.

Mitchell AD, Scholz AM \& Conway JM (1998) Body composition analysis of small pigs by dual-energy X-ray absorptiometry. Journal of Animal Science 76, 2392-2398.

Morel PCH, Maqhashalala LNV \& Purchas RW (1999) Effect of porcine somatotropin administration before weaning on growth performance in pigs. In Manipulating Pig Production VII, pp. 121 [PD Cranwell, editor]. Werribee, Victoria: Australasian Pig Science Association.

Neilsen H (1964) Effects in bacon pigs of different levels of nutrition to $20 \mathrm{~kg}$ bodyweight. Animal Production 6, 301-308.

Owens PC, Conlon MA, Campbell RG, Johnson RJ, King R \& Ballard FJ (1991) Developmental changes in growth hormone, insulin-like growth factors (IGF-I and IGF-II) and IGF-binding proteins in plasma of young growing pigs. Journal of Endocrinology 128, 439-447.

Owens PC, Johnson RJ, Campbell RG \& Ballard FJ (1990) Growth hormone increases insulin-like growth factor-I (IGF-I) and decreases IGF-II in plasma of growing pigs. Journal of Endocrinology 124, 269-275.

Payne RW, Lane PW \& Genstat 5 Committee (1993) Genstat 5 Reference Manual. Oxford Science Publications: Oxford, UK.

Ramsay TG, Hausman GJ \& Martin RJ (1987) Pre-adipocyte proliferation and differentiation in response to hormone supplementation of decapitated fetal pig sera. Journal of Animal Science 64, 735-744.

Sandles LD \& Peel CJ (1987) Growth and carcass composition of pre-pubertal dairy heifers treated with bovine growth hormone. Animal Production 44, 21-27.

Smith VG \& Kasson CW (1990) Growth performance and carcass characteristics of pigs administered recombinant porcine somatotropin during 30 to 110 kilogram live weight Journal of Animal Science 68, 4109-4116.

Suster D, Leury BJ, Wark JD, Kerton DJ, Ostrowska E \& Dunshea FR (2000) Dual energy X-ray absorptiometry to predict whole body and carcass composition in pigs. Journal of Animal Science 78, Suppl. 1, 145.

Wang Y, Fried SK, Petersen RN \& Schoknecht PA (1999) Somatotropin regulates adipose tissue metabolism in neonatal swine. Journal of Nutrition 129, 139-145.

Weeden TL, Nelssen JL, Goodband RD, Hansen JA, Friesen KG \& Richert BT (1993) The interrelationship of porcine somatotropin administration and dietary phosphorus on growth performance and bone properties in developing gilts. Journal of Animal Science 71, 2683-2692.

Wester TJ, Davis TA, Fioretto ML \& Burrin DG (1998) Exogenous growth hormone stimulates somatotropic axis function and growth in neonatal pigs. American Journal of Physiology 274, E29-E37.

Williams IH (1976) Nutrition of the young pig in relation to body composition, $\mathrm{PhD}$ Thesis, University of Melbourne.

Young LG \& Sharma VD (1973) Influence of energy intake by the neonatal pig on subsequent growth and development. Journal of Animal Science 36, 183-187. 